\title{
Effects of corporate social responsibility performance (CSR) on stock prices: Empirical study of listed manufacturing companies in Nigeria.
}

\author{
${ }^{1}$ Solomon Adeoluwa Zaccheaus, ${ }^{2}$ Oyerogba Ezekiel Oluwagbemiga, \\ ${ }^{3}$ Olaleye Michael Olugbenga \\ ${ }^{1,2,3}$ Department of Economics, Account and Finance School of Business Jomo Kenyatta University of Agriculture \\ and Technology
}

\begin{abstract}
This study investigates the effect of Corporate Social Responsibility Performance on stock prices of Nigerian listed manufacturing companies. The objective of this study is to carry out an empirical study of the relationship between Corporate Social Responsibility Performance and stock prices of listed manufacturing companies in Nigeria. We attempt to measure the perception and reaction of financial markets to the companies' socially responsible behaviors, and try to find out if an improvement in firm corporate social responsibility(CSR) actions has effects on stock prices. In our empirical analysis, we carried out tests that revealed the relationship between firms' corporate social responsibility performance(expenditure) and its influence on stock prices. Our empirical analysis revealed evidence of no relationship between corporate social responsibility performance and stock prices and evidence of no significant effect on stock prices of listed manufacturing companies in Nigeria We measured corporate social responsibility performance in terms of monetary contributions made or expenditure incurred by companies in respect of their social responsibility activities concerning environment, community and employment activities. Our findings show that listed manufacturing companies', in Nigeria ,Corporate Social Responsibility Performance(CSRP) has no effect on their stock prices and it further revealed a negative non-significant correlation between stock prices and corporate social responsibility (CSR) activities ..
\end{abstract}

Keywords: Corporate Social Responsibility, Corporate social responsibility performance, Stock Price.

\section{Introduction.}

1.1Background of the study.

Corporations carry out their business operations within social environments. Corporate business activities create interactions between the corporations and the environments within which they operate. A business needs a healthy, educated workforce, sustainable resources, and adept government to compete effectively.Forconducive andfriendlybusiness environments corporations usually participatein some environmental and social activities within their environments. These social and environmental activities may includemonetary donations and aid given to local and non-local non-profit organizations and communities, including donations in areas such as the arts, education, housing, health, social welfare, and the environment, donations of money and materials to motherless homesand government hospitals, awarding of scholarship to indigent students, control of environmental air, land and water pollution drainage cleaning, constructions and free donation of public school buildings, construction of roads, public toilets, employment of disable persons etc. These Corporate participations and involvements in social and environmental activities are referred to as corporate social responsibility. Corporate social responsibility(CSR) creates favourable goodwilland makes social and business environments conducive and friendly. A conducive and friendly social and business environment will enable corporations to achieve their main objective of profit and shareholders' wealth maximisation. According toCramer(2003), CSR implementation can provide opportunities to a firm and lead to added value. Holmes (1976), stated that improved reputation and enhancement of social community are the most expected positive results of CSR while the decrease of short- run profitability and conflict among social and financial goals are the possible negative outcomes in the view of executives. Van Dijken( 2007), argued :'stock markets will not value positively charitable and unpublicized contributions by a firm unless they have impact on firm's reputation'.CSR activities may help companies gain a possible listing in the stock exchange, or other similar listing. This may enhance the company's stock price, stock and stock options more profitable and shareholders happier (Robins, 2011) . According toAjide(2014),Corporate Social Responsibility (CSR) is the organisation's activity to make sustainable impact in society, and which in turn has the potential to create positive effect on the business organizations that engage in it. Business organizations incur huge expenditures on social responsibility because they regard Corporate Social Responsibility (CSR) as a public relations stunt used by large corporations to look good in front of customers and other stakeholders.Alessiaetal(2009) argued : 
'the quality of relationships that a company has with its employees and other key stakeholders-such as customers, investors, suppliers, public and governmental officials, activists, and communities-is crucial to its success, as is its ability to respond to competitive conditions and corporate social responsibility (CSR)'. Although there have been substantial research in developed countries on corporate social responsibility and corporate stock prices but limited attention has been given to it in developingcountries especially in Nigeria The reason for this might be little importance placed on the influence of corporate social responsibility on corporate stock prices .Consequently, in Nigeria, determining the effect of corporate social responsibility on corporate stock prices has been a challenging area for researchers. There have not been wide studies in Nigeria that examined the relationship between and effect of corporate social responsibility on corporate stock prices. This study is an attempt toexaminethe relationship between corporate social responsibility and stock pricesand its effect on stock prices of listed manufacturing companies in Nigeria.

\subsection{Statement of the Problem}

The relationship between CSR and corporate stock prices has been documented in the literature to date. Ideally, CSR and firm stock prices should be correlated, but studies on CSR and stock prices have yielded mixed results - positive, negative ,and neutral impact. There are studies that concluded that the contradictory results of previous studies reporting positive, negative, and neutral financial impact,were due to flawed empirical analysis. McWilliams and Siegel (2000), compared existing econometric studies of the relationship between social and financial performance and concluded that when the model is properly specified; that is, when you control for investment in Research and Development, an important determinant of financial performance, CSR has a neutral impact on financial outcomes.However,Orlitzkyetal,(2003), found a correlation between social/environmental performance and financial performance. 'A firm's implementation of CSR goes beyond compliance and engages in "actions that appear to further some social good, beyond the interests of the firm and that which is required by law.CSR is a process with the aim to embrace responsibility for the company's actions and encourage a positive impact through its activities on the environment, consumers, employees, communities, stakeholders and all other members of the public sphere who may also be considered stakeholders'(McWilliams, Siegel 2001).The term "corporate social responsibility" became popular in the 1960s and has remained a term used indiscriminately by many to cover legal and moral responsibility more narrowly construed(DeGeorge,2010).Corporate social responsibility is predominantly considered as a western phenomenon due to strong institutions, standards, and appeal systems which are weak in developing countries (Chapple and Moon, 2005). Such weak standards pose considerable challenge to firms for practicing CSR in developing countries including Nigeria. Though extensive research on CSR influencing firm performance has been carried out in developed countries (Belal, 2001), but there is a dearth of such studies in Nigeria. This study therefore seeks to fill the gap by examining the effect ofCSR on stock prices of listed manufacturing companies in Nigeria.

\subsection{Objectives of the Study}

The objectives of the study are as follows:

(i) To establishthe relationship between CSR performance and stock prices .

( ii)To establish the correlation between CSR and stock prices.

(iii) To test the effect of CSRP expenditure on stock prices.

\subsection{Significance of the study}

The study will contribute to the existing body of knowledge on CSR and stockprices. It also aims at making up for the limitedscholarly research in Nigeria on the impact of CSR on stock prices and relationship between firm's CSR and stock prices. The findings of this study will aid corporate executives to understand the importance of CSR in governance and decision making processes. The results aim at persuading managers to implement CSR actions in a greater extent in order to enhance their firm stock value.

\subsection{Research questions}

The following are research questions that guided the study:

i) are there relationships between corporate CSR performance and stock prices?

ii) is there correlation between CSRP and Stock prices

iii) what is the effect of CSRP expenditure on stock prices?

\section{Literature Review}

Corporate Social Responsibility (CSR) has received increasing attention in the past decades, both among practitioners and in the academic literature (Flammer, 2012). The definition of Corporate Social Responsibility (CSR) is an issue that dominates the existing literature. Davis (1973) defined CSR as "the firm's 
considerations of, and response to, issues beyond the narrow economic, technical, and legal requirements of the firm to accomplish social benefits along with the traditional economic gains which the firm seeks". The World Business Council for Sustainable Development (1999) refers to CSR as the continuing commitment by business to behave ethically and contribute to economic development while improving the quality of life of the workforce and their families as well as of the local community and society at large. There is also a disagreement on the definition of CSR among those that see CSR as an ethical attitude and those who argue that it is a firm's strategy (Wan-Jan, 2006). Stainer (2006) states that CSR concept is to show that ethical principles, from wherever derived, can improve reasoning and harmonize decisions, especially in complex situations and thus, enhance performance The unclear state of CSR definition is recognized also by Dahlsrud (2008). It has become a necessity for companies to deal with issues that concern all kinds of stakeholders, either internal or marketrelatedIsaksson and Steimle (2009), emphasized this need by arguing that CSR is the "company's commitment to behave socially and environmentally responsible while striving for its economic goals. However, a CSR action ought to be correlated with the financial state and outcomes of firms. Therefore, many studies were concentrated on the link between CSR and economic or financial firms' performance. CSR actions and economic state are seen either as competitive or complementary issues by many authors (Godfrey and Hatch, 2007). The latter view is supported by Friedman (1970), whostated that the only social responsibility of a firm is to maximize its profits, as to stay in the game of market without deception or fraudFor a business to take responsibility for its actions, that business must be fully accountable. The relationship between a firm CSR activities and corporate financial performance, i.e, stock prices has been a subject of conflicting debates in academic literature. Some authors like McWilliams and Siegel, (2001), Fauzi,(2009),Fiorie tal,(2009) argue for no relationship, but most consider that one exists. Some models establish a positive link.Ruie tal,(2013), report that companies who practice CSR saw more stability with their stock prices. The CSR increases the financial performance because of the satisfaction of goals of stakeholders (Freeman, 1984) and the improvement of public image and reputation of the firm (Wad- dock and Graves, 1997). Other models state a negative link(Wood and Jones,(2005), Brammeretal,(2006). The costs expend due to the CSR of the firm ((Friedman, 1962) and (Friedman, 1970)) reduce the firm's competitiveness and its financial performance, Preston and O'Bannon (1997) suppose a synergy, positive or negative. On one hand, a virtuous circle is considered by Waddock and Graves (1997). A high level of CSR performance leads to a better financial performance which authorized new CSR actions. On the other hand, a poor CSR performancereduces financial performance and thus CSR expenditures. They are difficultto compare directly because of limits concerning concepts, methodologies and data used (Allouche and Laroche, 2006). Marc Orlitzky (2003) supports a positive link between CSR and financialperformance. 'CSRhelps improve managerial knowledge and skills and enhance corporate reputation" (Orlitzky, 2008). Different benefitsare obtained, mainly: increased efficiency, increased sales revenues, reduction of business risk and specially the shareholder risk.Durnev(2013) argued: 'a healthy dose of CSR created greater brand loyalty, so customers kept buying their products and paid a premium for them, despite what the overall economic situation was. That stability of sales in turn reduces the companies' costs of equity capital, further reducing its overall risk'. CSR seems to be more related to accounting measures of financial performance than capital markets measures. Allouche and Laroche (2006) stated that reputation indexes are correlated with financial market measures more than accounting ones. But, the relationship between CSR and financial performance is not completely determined due to the action of many moderators, such as characteristics of firms, industry and economic situation. Moreover, CSR interact with financial risk factors, for instance with Fama\& French factors, as demonstrated by Galema et al. (2008). Further, some authors underline ambiguity of the links. So, even where positive relation can be shown, more research is needed to better understand the links and interactions between CSR and financial performance. Bowman and Haire (1975) suggesteda non-linear relationship between CSR and financial performance. The literature focusing on the impact of CSR on capital market performance and shareholder wealth reveals contrasted results. Studies on specific aspects, as announcement of corporate donation or producing environmentally-friendly products show a positive link (Hall and Rieck, 1998). Ron and Reggiani (2007) suggest that share values are not only influenced by CSR components, but also by the whole CSR activities, in a way varying over time. Durnevetal(2013) noticed that companies that were first, or early adopters, into CSR in their industry gained a larger market share and had less volatility in its stock prices than companies that began CSR later. "I think you'll see CSR having a more and more stabilizing effect on companies' stock prices in the future," Durnev said. "Interest in CSR isn't something that's going to go away."

\subsection{Research Design}

\section{Methodology}

The research design used in this study was an empirical cross-sectional design. This is a study in which data is gathered systematically over a period of time in order to answer a research question. Data analysis was 
carried out to determine : (i) the relationship between firms' CSR performance and stock prices of listed manufacturing companies in Nigeriaand, (ii) the effect of firms' CSR activities on stock prices.

\subsection{Population and Sample.}

The target population comprised of all manufacturing companieslisted on Nigeria Stock Exchange(NSE). The population of the study was all 73 manufacturing companieslisted on Nigeria Stock Exchange(NSE) as at the end of 2012 .The population of the study was grouped into stratum on the basis of industries and products. A sample size of 30 companies were selected for study on stratified basis . The selection of the sample in each group(stratum) was based on the proportion of the number of firms in each stratum in the population .

\subsection{Data Collection Methods}

In this study, we used secondary data, which is the companies annual financial statements, because they are readily available online( Nigeria Annual Reports list and Nigerian Stock exchange annual reports) and at the corporate head offices of the companies. Data for studies were extracted from the annual financial statements of the listed manufacturing companies considered for the study.

\subsection{Data Analysis}

Inferential statistics were employed in analyzing the data. Data were analyzed using simple OLS regression model, describing the variable as dependent variable, and independent variable. A computer package EXCEL was employed to solve the simple regression equation used in this study. In analyzing the relationship between corporate social responsibility and its effect on stock prices, we considered the firm averageexpenditure on corporate social responsibility and the firm average stock prices over the period of our study(2008-2012).The sample period is determined by the availability of data. The study considered functional form relationship between CSR expenditure and the stock prices. Our theoretical model is:

$\mathrm{P}_{\mathrm{t}}=\mathrm{f}\left(\mathrm{X}_{\mathrm{t}-1}\right)(1)$

$\mathrm{P}_{\mathrm{t}}=\mathrm{A}+\mathrm{BX}_{\mathrm{t}-1}+\mathrm{U}_{\mathrm{t}}$

Where :

$P_{t}$ is the average stock price of each of the companies for the five years (2008-2012) period of study. $\mathrm{X}_{\mathrm{t}-1}$ is the average corporate social responsibility expenditure per share for each of the companies for five years(2008-2012) period of study.

Bisthe coefficient used to measure the average stock price sensitivity to a unit change in the average corporate social expenditures per share.

$\mathrm{U}_{\mathrm{t}} \mathrm{is}$ the error term.

$\mathrm{A}$ is a constant term.

In our analysis, we introduce a one year lag between dependent and independent variables . To test the relationship between stock price and corporate social responsibility, we conducted regression analysis. t-test statistic is employed to measure the degree of the influence( significance) of corporate social responsibility expenditure on stock price. $\mathrm{R}^{2}$ is used to measure the extent to which the stock price is determined by corporate social responsibility expenditure, and $\mathrm{r}$, correlation coefficient, is used to measure the relationship between the stock price (the dependent variable) and corporate social responsibility expenditure(independent variable).

The hypothesis that we examined are:

Hypothesis 1:

Ho: There is norelationship between a firmcorporate social responsibility expenditureand stock prices. Hypothesis2:

Ho: A firm CSR expenditure has no effect on stock prices

\section{Results}

With a view to determining the correlation between CSR and stock prices and CSR influence on stock prices, we examined the correlation coefficient between the stock prices and CSR and carried out a test of the parameter of the explanatory variable(CSR), using t-statistic at 5\% level.

4. 1Correlation Results. The correlationcoefficient( $\mathrm{r}$ ) for the dependent and independent variable is -0.1283 and $\mathrm{X}_{\mathrm{t}-1} \mathrm{P}-$ Value $=0.7840$. As can be seen, the correlation coefficient ( $\mathrm{r}$ )is very low and insignificant and PValue is too high.These results suggest that there is no relationship between firms'CSR performance(expenditure) and stock prices on the Nigerian Stock Exchange market . These results show that CSR performance has no relationship with stock prices of listed manufacturing companies in Nigeria. This finding confirms our hypothesis 1 and is consistent with the findings of McWilliams and Siegel(2001), Kang etal(2010), D'Arcimoles and Trebucg,(2002) which suggest neutral relationship between CSR and stock prices. Also, our findingshows anegative and non- significant correlation between CSR and stock prices of listed 
manufacturing companies in Nigeria.This finding also agrees with the findings of Wood and Jones(2005), Vance(1975).

4.2Regression Analysis. To test theeffect of firmcorporate social responsibility expenditure on stock prices, we carried out regression analysis. Table 1 gives the results of our econometric model. Thesimple coefficient of determination $\left(\mathrm{R}^{2}\right)$ is 0.01645 . This implies that only about 1.65 percent of the variation on stock price is explained by firm CSR expenditure . Moreover, the coefficient of Xt-1(B) is -362.744 , its standard error is 1254.234 and its t-statistic is -0.282 . Our test ,two tail test, shows that the coefficient of Xt-1(CSR expenditure) is not significant at the $5 \%$ level $(\mathrm{p}=0.7840)$. This result confirms our hypothesis 2 and is consistent with the findings of Fauzi(2009), Mahoney and Roberts(2002), Goukasian and Whitney(2008) that find neutral relationship between CSR and stock price.This result shows that Nigerian listed manufacturing companies' CSR expenditure has no effect on their stock prices.

Table 1: Model Summary

Regression Equation : $\mathrm{P}_{\mathrm{t}}=147.064-362.744 \mathrm{X}_{\mathrm{t}-1}$

Standard Error: 90.384 .1254 .234

t-statistic : $\quad(1.627)(-0.282)$

$\mathrm{P}$-Value : $0.1650 .7840 \mathrm{R}^{2} 0.016453891$

AdjustedR ${ }^{2}=-0.18025533$

\subsection{Conclusion and Recommendation}

There are a lot of reasons why companies in Nigeria engage in corporate social responsibility (CSR). Somepractice it in active compliance with the law, creation of goodwill,friendlyconducive business environment, and because it is the right thing to do for the society and environment. And others practice it, because they see it as good public relations and ethical.

This study is an effort to establish the relationship of CSR and firms' stock prices in the listed Nigerian manufacturing companies. We attempt to find out if firmsCSR actions have effect on stock prices.. Data are obtained for five-year period using one year lag. The results of our research are consistent with the larger portion of studies. A negative and non significant relationship between stock prices and CSR is found. The results of our econometric model appears to be statistically insignificant and show that there is no relationship between firms' CSR and stock prices and that firms'CSR performance has no effect on stock prices. Given our findings, we recommend that firms should engage in only necessary CSR activities, such as compliance with the law, ethic, building favorable business atmosphere, and a good marketing strategy, because it is not an important variable considered in valuing shares at the stock market .

We also recommend that firms should engage in social responsibility activities because, a socially responsible firm is likely to have good reputation which may enable itto remain in business over a longer period of time and its survival will likely be less threatened.The simple reason for it,is that these firms have built greater loyalty and commitment from their stakeholders.

The relationship between corporate social responsibility and stock prices is an area that has not been researched thoroughly in Nigeria, we thereforesuggest that future research should focuson resolving the controversies surrounding the effect of CSR on stock prices.

\section{References}

[1]. Ajide, Folorunsho Monsuru1, Aderemi, AdetunjiAbdulazeez(2014)The effects of corporate social responsibility activity disclosure on corporate profitability: Empirical evidence from Nigerian commercial banks .IOSR Journal of Economics and Finance (IOSRJEF).Volume 2, Issue 6 (Feb. 2014), PP 17-25.

[2]. Alessia ,D.,Sybil, H. And Sue, F;(2009), 'Corporate social responsibility and sustainablebusiness', Auide to Leadership Tasks and Functions,Center for creative Leadership, Greenboro, North Carolina

[3]. Allouche, J., Laroche, P., 2006. The Relationship Between Corporate Social Responsibility and Corporate Financial Performance: A Survey. Palgrave MacMillan, New York. pp. 3-40.

[4]. Belal, A.: 2001, 'A Study of Corporate Social Disclosures in Bangladesh', Managerial Auditing Journal 15(5), $274-289$.

[5]. Bowman, E.H., Haire, M., 1975. A strategic posture toward corporate social responsibility. California Management Review 18, 4958 .

[6]. Brammer, S., Brooks, C. and Pavelin, S., 2006, "Corporate Social Performance and Stock Returns: UK Evidence from Disaggregate Measures", Financial Management 35(3), 97-116.

[7]. Caroline Flammer(2012) Corporate Social Responsibility and Stock Prices:The Environmental Awareness of Shareholders MIT Sloan School of Management,May, 2012.

[8]. Chapple, W. and J. Moon: 2005, 'Corporate Social Responsibility in Asia: A Seven-Country Study of CSR Web Site Reporting', Business \& Society 44(4), 415-441.

[9]. Cramer, J., 2003. “Corporate Social Responsibility: Lessons Learned”, Environmental Quality Management 13(2), 59-66.

[10]. Graves, S.B., Waddock, S.A., 1994, "Institutional owner and corporate social performance", The Academy of Management Journal 37(4), 1034-1046.

[11]. D'Arcimoles, C.-H. andTrebucq, S., 2002, "The corporate social performance - financial performance link: evidence from France", Working Paper Series, Available at SSRN: http://ssrn.com/abstract=306599 (accessed 14 April 2010).

[12]. Dahlsrud, A., 2008, "How Corporate Social Responsibility is Defined: an Analysis of 37 Definitions", Corporate Social Responsibility and Environmental Management 15(1), 1-13. 
[13]. Davis, K., 1973, "The Case for and against Business Assumption of Social Responsibilities", The Academy of Management Journal 16(2), 312-322. .

[14]. DeGeorge, Richard T. Business Ethics. 7th. Upper Saddle River: Pearson Education, Inc. , 2010. 200. Print

[15]. Fauzi, H., 2009, "Corporate Social and Financial Performance: Empirical Evidence from American Companies", Globsyn Management Journal, Forthcoming, Available at SSRN: http://ssrn.com/abstract=1489494 (accessed 14 April 2010).

[16]. Fiori, G., Di Donato, F. and Izzo, M.F., 2009, "Corporate social responsibility and firms performance. An analysis on Italian listed companies", paper presented at the Performance Measurement Association Conference (PMA), 14 April-17 April, Dunedin, New Zealand, available at: http://www.pma.otago.ac.nz/pma- cd/papers/1034.pdf (accessed 22 October 2010).

[17]. Folger, H. and Nutt, F., 1975, “A note on social responsibility and stock valuation", Academy of Management Journal 18(1), 155160.

[18]. Freeman, R. E., 1984, Strategic management: A stakeholder approach (Pitman, Boston).

[19]. Friedman, M., 1970, “The social responsibility of business is to increase its profits”, New York Times Magazine, 13 Sep., pp. 33.

[20]. Galema, R., Plantinga, A., Scholtens, B., 2008. The stocks at stake: Return and risk in socially responsible investment. Journal of Banking \& Finance 32, 2646-2654

[21]. Godfrey, P. and Hatch, N., 2007, "Researching Corporate Social Responsibility: An Agenda for the 21st Century", Journal of Business Ethics 70(1), 87-98.

[22]. Goukasian, L. and Whitney, K.L., 2008, “Corporate Socially Responsible Firms Perform Well! Evidence from Financial and Operating Performances", Working Paper Series. Available at SSRN: http://ssrn.com/abstract=972649 (accessed 14 April 2010 ).

[23]. Hall, P.L., Rieck, R., 1998. The effect of positive coporate social actions on shareholder wealth. Journal of Financial and Strategic Decisions 11, 83-89.

[24]. Holmes, S.L., 1976, "Executive perceptions of corporate social responsibility", Business Horizons 19(3), 34-40.

[25]. Isaksson, R. and Steimle, U., 2009. “What does GRI-reporting tell us about corporate sustainability?”, The TQM Journal 21(2), $168-181$.

[26]. Kang, K.H., Lee, S. and Huh, C., 2010, "Impacts of positive and negative corporate social responsibility activities on company performance in the hospitality industry", International Journal of Hospitality Management 29(1), $72-82$.

[27]. Mahoney, L. and Roberts R.W., 2007, "Corporate social performance, financial performance and institutional ownership in Canadian firms", Accounting Forum 31(3), 233-253.

[28]. McWilliams, Abagail; Siegel, Donald (6 April 2000). "Corporate social responsibility and financial performance: correlation or misspecification?".Strategic Management Journal21 (5): 603-609. doi: $10.1002 /($ SICI)1097-0266(200005)21:5<603::AID$\underline{\mathrm{SMJ} 101>3.0 . \mathrm{CO} ; 2-3}$

[29]. McWilliams, A., Siegel, D., 2001. Corporate social responsibility: A theory of the firm perspective. The Academy of Management Review 26, 117-127

[30]. Orlitzky, Marc; Frank L. Schmidt, Sara L. Rynes (2003). "Corporate Social and Financial Performance: A Meta-analysis" (PDF).Organization Studies (London: SAGE Publications) 24 (3): 403-441. doi: $10.1177 / 0170840603024003910$. Retrieved 200803-

[31]. Orlitzky, M., 2008. Corporate social performance and financial performance, in: The Oxford Handbook of Corporate Social Responsibility. Oxford Uni- versity Press.

[32]. Preston, L., O’Bannon, D., 1997. The corporate social-financial performance relationship. Business and Society 36, 419-429.

[33]. Ron Bird, Anthony D. Hall, F.M., Reggiani, F., 2007. What corporate social responsibility activities are valued by the market? Journal of Business Ethics 76, 189-206

[34]. Robins R. (May, 2011).Does corporate social responsibility increase profits?Business Ethics -The magazine of corporate social responsibility. Available online at www.business-ethcs.com. Accessed on 23th October,2013.

[35]. Stainer, L., 2006, "Performance management and corporate social responsibility: the strategic connection", Strategic Change 15(5), 253-264.

[36]. Van Dijken, F., 2007, “Corporate social responsibility: market regulation and the evidence”, Managerial Law 49(4), 141-184.

[37]. Vance, S. C., 1975, “Are socially responsible corporations good investment risks?”, Management Review 64 (8), 18-24.

[38]. Waddock, S.A. and Graves, S.B., 1997, "The corporate social performance - financial performance link", Strategic Management Journal 18(4), 303-319.

[39]. Wan-Jan, W.S., 2006, "Defining corporate social responsibility", Journal of Public Affairs 6(3-4), $176-184$.

[40]. Wood, D.J. and Jones, R.E., 2005, "Stakeholder mismatching: a theoretical problem in empirical research on corporate social performance", The International Journal of Organizational Analysis 3(3), 229-267.

[41]. World Business Council for Sustainable Development, 1999, "Corporate Social Responsibility: Meeting Changing Expectations" (World Business Council for Sustainable Development, Geneva).

Appendix:

CSR Corporate social responsibility. 